\title{
SISTEM INFORMASI ENTERPRISE PADA BALI ETAWA FARM
}

\author{
Pande Made Widiarjaya WD ${ }^{1}$ \\ I Gede Juliana Eka Putra ${ }^{2}$ \\ I Nyoman Yudi Anggara Wijaya ${ }^{3}$
}

\author{
STMIK Primakara, Denpasar, Bali, Indonesia ${ }^{1,2,3}$ \\ email: pandewidiarjayazw@gmail.com
}

\begin{abstract}
Information technology has developed in various fields of life. Along with these developments, technology also plays a very important role in agriculture and animal husbandry. However, the Bali Etawa Farm company has not utilized information technology so that in carrying out its business processes there are obstacles. One of the obstacles facing Bali Etawa Farm today is that the existing processes are not yet integrated, both in terms of production, sales and warehouse processes. With these problems, it is necessary to create an Enterprise Information System to integrate all processes in Bali Etawa Farm. The research method used in this research is the waterfall method which is also called the classic life cycle and data collection is interviews, observation and documentation at Bali Etawa Farm. Based on the results of data collection, the constraints and flow of business processes that exist at Bali Etawa Farm are identified. From these results, a system design, database design and interface design are made, from these designs then poured into the coding to make the system, after the system is completed, the system will be tested. The results of system testing are as expected so that the enterprise information system has been successfully created.
\end{abstract}

Keywords: $\quad$ agriculture, enterprise information systems, the waterfall method

\section{PENDAHULUAN}

\section{Penggunaan}

teknologi

informasi saat ini sudah berkembang dalam berbagai bidang, tidak hanya digunakan pada perusahaan perusahaan besar seperti: Bank, Rumah Sakit, Perkantoran, Industri, dan Sekolah namun juga sudah berkembang pada bidang Pertanian maupun Perternakan. Hal ini mengubah sistem yang dibuat secara manual pada umumnya menjadi terkomputerisasi dan terintegrasi sehingga data yang diperoleh dapat menghasilkan informasi bagi pengguna dengan mudah dan cepat. Salah satunya seperti sistem produksi, penjualan dan persediaan.
Bali Etawa Farm merupakan pertanian terbesar yang ada di Bali yang bergerak dalam bidang pengolahan susu kambing. Bali Etawa Farm berlokasi di Desa Sepang, Kecamatan Busungbiu, Kabupaten Buleleng. Besarnya sektor peternakan di desa ini mendorong penduduk untuk meningkatkan nilai ekonomis dari peternakan kambing yaitu berupa daging sebagai bahan makanan, kotoran kambing sebagai pupuk dan susu kambing yang dijual mentah. Namun nilai ekonomis dari susu kambing yang dijual mentah sangatlah rendah. Melihat peluang inilah Bali Etawa Farm mengolah susu kambing tersebut menjadi produk kecantikan 
dengan nilai lebih tinggi seperti: Handbody, Sabun, dan Shampoo.

Proses produksi yang dilakukan langsung oleh Bali Etawa Farm memiliki beberapa masalah, salah satu permasalahan yang dihadapi Bali Etawa Farm saat ini adalah belum terintegrasinya proses yang ada, baik dari segi proses produksi susu kambing yaitu ketidaktahuan informasi jumlah satuan liter susu kambing yang diproduksi setiap harinya karena setiap produksi langsung di sterilkan dan dimasukkan ke freezer, kemudian dari segi produksi olahan susu kambing yang tidak diketahui berapa jumlah stok susu kambing yang akan digunakan untuk olahan, baik itu berupa sabun, handbody dan shampoo, hingga penjualan dari hasil olahan tersebut yang tidak diketahui berapa stok barang sehingga data yang diolah menjadi informasi belum terintegrasi dengan maksimal.

Berdasarkan permasalahan yang telah disampaikan diatas, tujuan dilakukannya penelitian ini adalah dengan membuat Sistem Informasi Enterprise yang dapat mengintegrasikan setiap proses yang ada pada Bali Etawa Farm sehingga akan memudahkan setiap divisi untuk mengontrol kegiatan produksi dan penjualan yang dilaksanakan. Selain itu sistem ini juga akan memudahkan owner dalam mengambil suatu kebijakan atau keputusan dan mengontrol pelaksanaan proses pada setiap divisi.

\section{TINJAUAN PUSTAKA}

\section{Enterprise}

Enterprise umumnya sering disamakan dengan pengertian organisasi atau perusahaan. Krisdanto Surendro (2009) menyebutkan bahwa enterprise bukan hanya perusahaan (company) yang berorientasi kepada profit saja, tetapi juga bisa berupa organisasi non-profit/nirlaba seperti pemerintah, institusi pendidikan ataupun organisasi amal, dalam hal ini Bali Etawa Farm perusahaan yang bergerak dibidang pertanian dan peternakan memiliki beberapa divisi sehingga bisa disebut dengan enterprise [1].

Enterprise Resource Planing (ERP)

Sistem Enterprise Resource Planning (ERP) adalah program perangkat lunak inti yang digunakan oleh perusahaan untuk mengintegrasikan dan mengkoordinasikan informasi dalam setiap area bisnis. ERP mendukung operasi yang efisien dari proses bisnis dengan mengintegrasikan tugas-tugas yang ada disetiap divisi pada Bali Etawa Farm yang berhubungan dengan produksi susu, produksi olahan susu, stok gudang, dan penjualan. Area operasi fungsional saling bergantung, masing-masing memerlukan data dari yang lain. Sistem yang terintegrasi dengan menggunakan perangkat lunak ERP menyediakan berbagai data yang diperlukan antara bidang fungsional [2].

\section{Metode Waterfall}

Metode Waterfall adalah suatu proses pengembangan perangkat lunak beruntun, dimana proses pengembangan dilakukan terus mengalir ke bawah mulai dari fase analisis kebutuhan, desain, penulisan program, hingga pengujian [3].

\section{METODE PENELITIAN}

Adapun metode penelitian yang digunakan pada penelitian ini adalah classic life cycle. Adapun tahapan classic life cycle adalah sebagai berikut : 


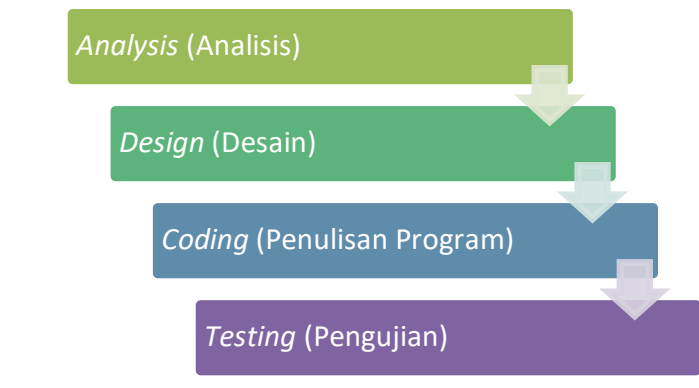

Gambar 1

Metode Pengembangan Classic Life Cycle

Berikut ini adalah tahapan pengembangan sistem menggunakan classic life cycle :

1. Tahap Analisis pada penelitian ini, data yang dikumpulkan oleh penulis adalah dalam bentuk kualitatif yang diperoleh dari hasil wawancara dan observasi dengan pemilik Bali Etawa Farm. Kemudian data tersebut penulis jadikan acuan dalam pembuatan alur sistem, rancangan antarmuka dan rancangan database sistem informasi yang akan dibangun. Selain itu, data tersebut juga penulis gunakan sebagai pertimbangan untuk menentukan fitur-fitur apa saja yang akan disediakan pada sistem informasi dan disesuaikan dengan kebutuhan pada Bali Etawa Farm.

2. Pada tahap desain, penulis membuat rancangan antarmuka Sistem Informasi dengan menggunakan tools Adobe Photoshop. Selain itu, penulis juga membuat rancangan sistem berupa usecase diagram dan rancangan database menggunakan Entity Relationship Diagram (ERD).

3. Tahap coding, penulis menggunakan framework laravel untuk membuat Sistem Informasi Enterprise karena framework ini memiliki komunitas yang sudah banyak sehingga mempermudah penulis dalam mencari referensi codingan untuk membuat sebuah sistem informasi

4. Tahap testing, nantinya penulis akan melakukan testing dari sistem informasi dengan menggunakan metode testing "Black Box" dengan cara langsung menggunakan sistem dengan mencoba memasukan inputan yang ada, apakah sudah sesuai dengan tujuan atau tidak.

\section{HASIL DAN PEMBAHASAN}

Pada hasil penelitian ini, penulis memberikan penjelaskan hasil dari penelitian yang dilakukan pada metodologi penelitian. Hasil tersebut akan dijelaskan secara terperinci dan jelas sebagai pembuktian dalam penelitian dan juga kedepannya dapat dikembangkan sebagai sistem yang nantinya dapat berguna bagi perusahaan. Berikut ini penjelasan dari hasil yang dilakukan pada penelitian ini:

\section{Hasil Rancangan Sistem}

Sistem Informasi Enterprise ini dirancang menggunakan bahasa pemodelan Unified Modelling Language (UML). Menurut Nugroho, "UML (Unified Modeling Language) adalah 'bahasa' pemodelan untuk sistem atau perangkat lunak yang berparadigma "berorientasi objek". 
Journal of Applied Management and Accounting Science ( J A M A S )

(Pande Made Widiarjaya WD, I Gede Juliana Eka Putra, I Nyoman Yudi Anggara Wijaya 1 - 11) Vol 2, No 1, Desember 2020

Pemodelan (modeling) sesungguhnya digunakan untuk penyederhanaan permasalahan-permasalahan yang kompleks sedemikian rupa sehingga

lebih mudah dipelajari dan dipahami”. Rancangan sistem usecase diagram Sistem Informasi Enterprise ini dapat dilihat pada gambar berikut.

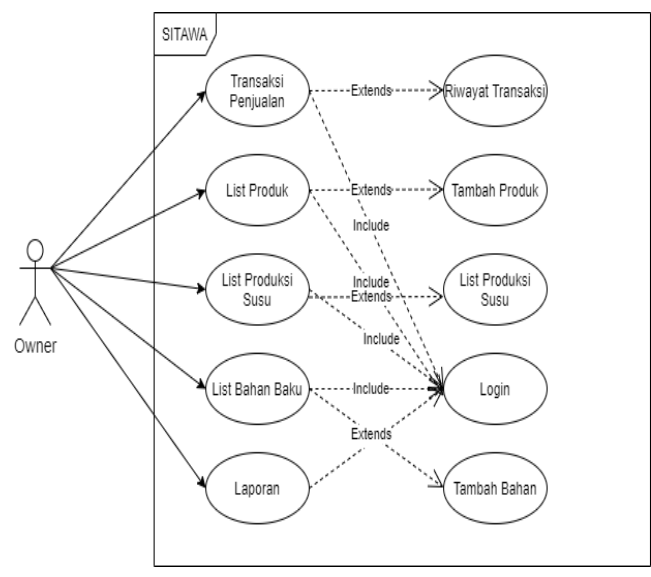

Gambar 2

\section{Usecase Diagram Sistem Informasi Enterprise pada Bali Etawa Farm}

\section{Sistem Informasi Enterprise pada Bali Etawa Farm}

Dari hasil penelitian dan rancangan yang penulis lakukan, maka dibuatlah Sistem Informasi Enterprise dimana sistem ini dapat membantu mengintegrasikan setiap proses yang ada pada Bali Etawa Farm sehingga akan memudahkan setiap divisi untuk mengontrol kegiatan yang dilakukan. Selain itu sistem ini juga memudahkan owner dalam mengambil suatu kebijakan atau keputusan dan mengontrol pelaksanaan proses pada setiap divisi.

a. Tampilan Login

Pada halaman login terdapat beberapa komponen yaitu: input untuk memasukkan username dan password, serta tombol login. Tampilan halaman login dapat dilihat pada gambar berikut:

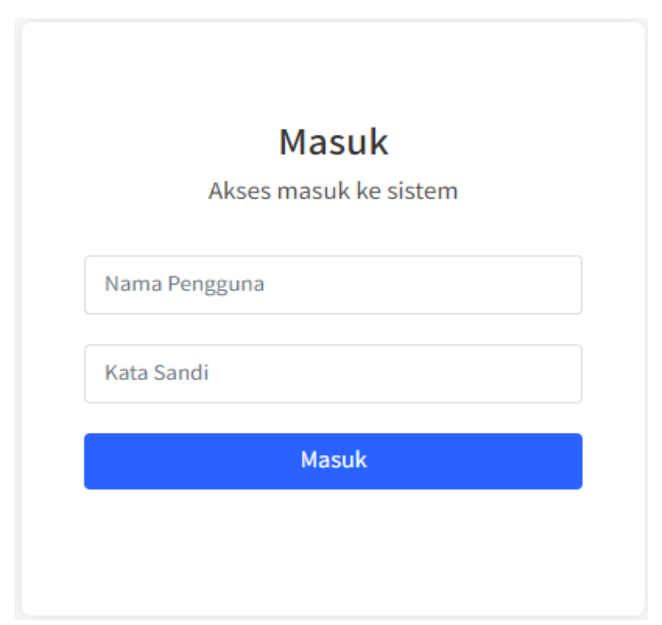

Gambar 4

Tampilan Login 
Journal of Applied Management and Accounting Science ( J A M A S )

(Pande Made Widiarjaya WD, I Gede Juliana Eka Putra, I Nyoman Yudi Anggara Wijaya 1 - 11) Vol 2, No 1, Desember 2020

b. Tampilan Halaman Admin

Pada halaman admin terdapat menu laporan dimana laporan tersebut dapat didownload berupa laporan penjualan, laporan pengeluaran dan laba rugi dengan, selain itu pada menu halaman utama ditampilkan grafik transaksi.

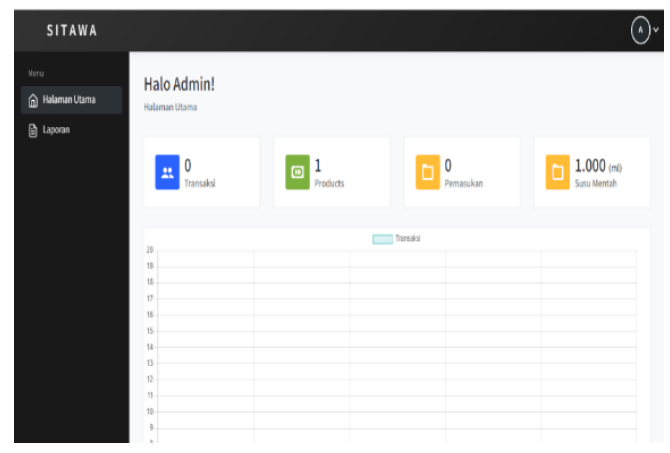

\section{Gambar 5}

\section{Tampilan Halaman Admin}

c. Tampilan Halaman Produksi Pada halaman produksi terdapat beberapa menu yaitu: halaman utama yang menampilkan stok susu, stok produk yang ditambahkan dan stok yang masih menunggu dari bagian gudang, menu produksi susu dan hasil produksi.

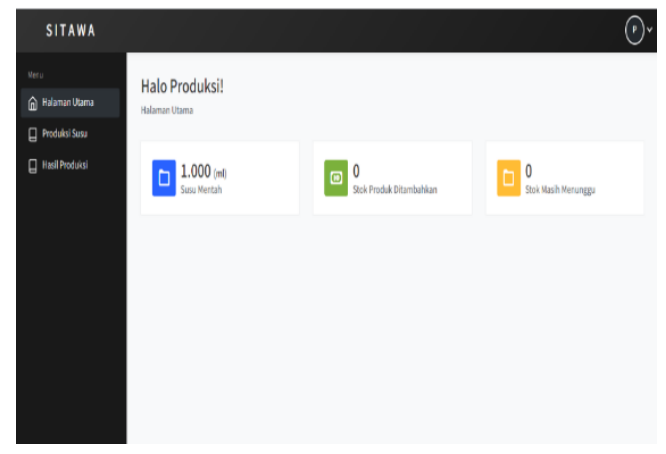

\section{Gambar 6}

\section{Tampilan Halaman Produksi}

d. Tampilan Halaman Gudang

Pada halaman gudang terdapat

beberapa menu diantaranya adalah bahan baku dan produk. Pada halaman bahan baku user akan menginputkan data bahan baku beserta jumlahnya. 
Journal of Applied Management and Accounting Science ( J A M A S )

(Pande Made Widiarjaya WD, I Gede Juliana Eka Putra, I Nyoman Yudi Anggara Wijaya 1 - 11) Vol 2, No 1, Desember 2020
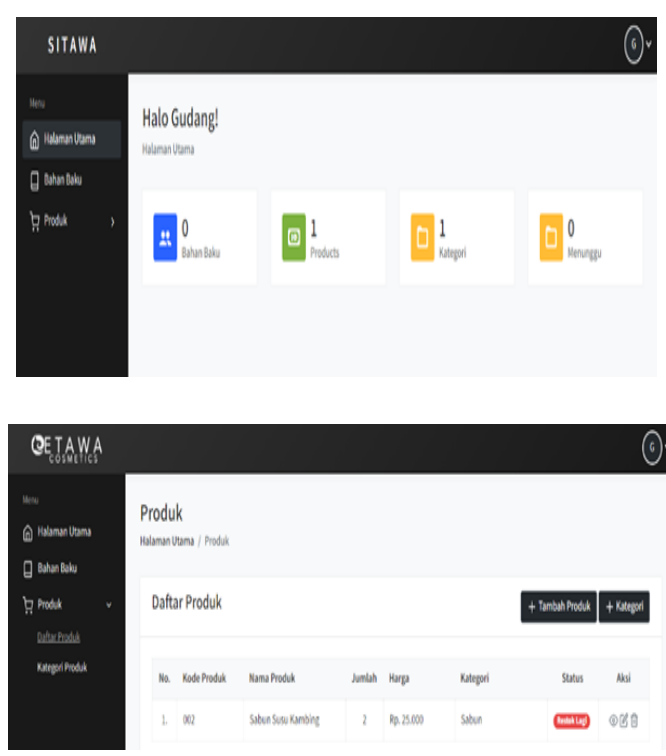

Gambar 7

Tampilan Halaman Gudang

e. Tampilan Halaman Transaksi

Pada tampilan halaman transaksi terdapat menu produk dan transaksi, dimana menu produk menampilkan daftar produk yang tersedia dan pada menu transaksi menampilkan transaksi baru dan riwayat transaksi.
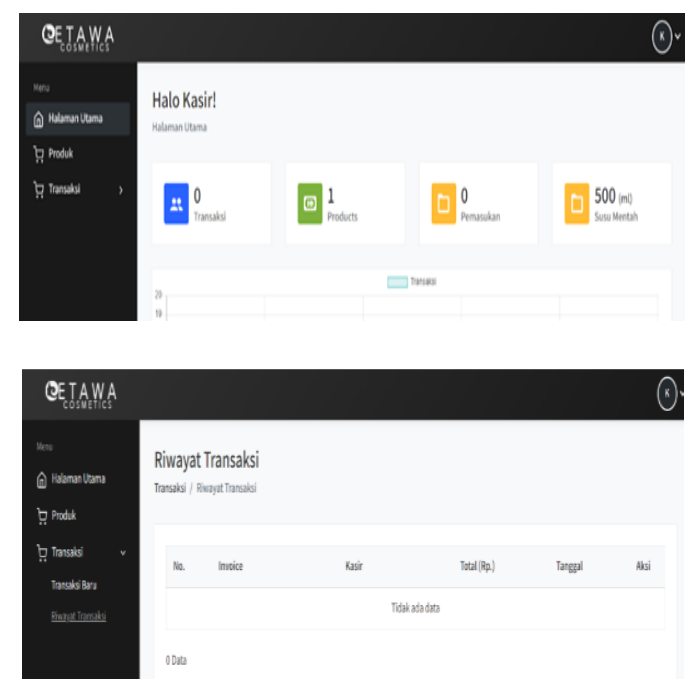

Gambar 8

Tampilan Halaman Transaksi

\section{Pengujian Sistem}

Dari hasil penelitian dan rancangan yang penulis lakukan, maka dibuatlah Sistem Informasi Enterprise dimana sistem ini dapat membantu mengintegrasikan setiap proses yang ada pada Bali Etawa Farm sehingga akan memudahkan setiap divisi. 
Journal of Applied Management and Accounting Science ( J A M A S )

(Pande Made Widiarjaya WD, I Gede Juliana Eka Putra, I Nyoman Yudi Anggara Wijaya 1 - 11) Vol 2, No 1, Desember 2020

\section{Tabel 1}

Pengujian Black Box pada Menu Sign In

\begin{tabular}{|c|c|c|c|}
\hline No & Skenario Pengujian & Hasil yang Diharapkan & Kesimpulan \\
\hline 1 & $\begin{array}{l}\text { Mengosongkan } \\
\text { Username dan } \\
\text { Password, lalu } \\
\text { langsung klik } \\
\text { tombol "Masuk", }\end{array}$ & $\begin{array}{l}\text { Sistem akan menolak } \\
\text { akses login dan } \\
\text { menampilkan pesan “ } \\
\text { Peringatan:The } \\
\text { username and password } \\
\text { field is required” }\end{array}$ & Valid \\
\hline 2 & $\begin{array}{l}\text { Hanya mengisi } \\
\text { Username dan } \\
\text { mengosongkan } \\
\text { Password, lalu } \\
\text { langsung klik } \\
\text { tombol "Masuk" }\end{array}$ & $\begin{array}{l}\text { Sistem akan menolak } \\
\text { akses login dan } \\
\text { menampilkan pesan } \\
\text { "Peringatan: The } \\
\text { password field is } \\
\text { required" }\end{array}$ & Valid \\
\hline 3 & $\begin{array}{l}\text { Hanya mengisi } \\
\text { Password dan } \\
\text { mengosongkan } \\
\text { Username, lalu } \\
\text { langsung klik } \\
\text { tombol "Masuk" }\end{array}$ & $\begin{array}{l}\text { Sistem akan menolak } \\
\text { akses login dan } \\
\text { menampilkan pesan } \\
\text { "The username field is } \\
\text { required" }\end{array}$ & Valid \\
\hline 4 & $\begin{array}{l}\text { Mengisi salah satu } \\
\text { inputan dengan } \\
\text { data benar dan data } \\
\text { salah, lalu klik } \\
\text { tombol "Masuk" }\end{array}$ & $\begin{array}{l}\text { Sistem akan menolak } \\
\text { akses login dan } \\
\text { menampilkan pesan } \\
\text { "Peringatan: These } \\
\text { credentials do not } \\
\text { match our records" }\end{array}$ & Valid \\
\hline 5 & $\begin{array}{c}\text { Mengisi Username } \\
\text { dan Password } \\
\text { dengan benar lalu } \\
\text { klik tombol } \\
\text { "Masuk" }\end{array}$ & $\begin{array}{l}\text { Sistem akan menerima } \\
\text { akses login }\end{array}$ & Valid \\
\hline
\end{tabular}

Tabel 2

Pengujian Black Box pada Menu Tambah Produksi Susu

\begin{tabular}{|c|c|c|c|}
\hline No & Skenario Pengujian & $\begin{array}{l}\text { Hasil yang } \\
\text { Diharapkan }\end{array}$ & Kesimpulan \\
\hline 1 & $\begin{array}{c}\text { Mengklik tombol } \\
\text { tambah (+) pada } \\
\text { tambah susu mentah } \\
\text { dihalaman produksi } \\
\text { susu }\end{array}$ & $\begin{array}{l}\text { Sistem akan } \\
\text { menampilkan } \\
\text { form tambah } \\
\text { susu }\end{array}$ & Valid \\
\hline 2 & $\begin{array}{l}\text { Mengisi inputan } \\
\text { jumlah produksi susu } \\
\text { lalu mengklik tombol } \\
\text { "Simpan" }\end{array}$ & $\begin{array}{l}\text { Sistem akan } \\
\text { menyimpan data } \\
\text { ke database dan } \\
\text { menampilkan } \\
\text { pesan "Data } \\
\text { Bahan berhasil } \\
\text { disimpan" }\end{array}$ & Valid \\
\hline 3 & $\begin{array}{c}\text { Mengosongkan } \\
\text { inputan, lalu } \\
\text { langsung klik tombol } \\
\text { "simpan" }\end{array}$ & $\begin{array}{c}\text { Sistem tidak } \\
\text { akan menyimpan } \\
\text { data dan } \\
\text { menampilkan } \\
\text { pesan "please fill } \\
\text { out this field" }\end{array}$ & Valid \\
\hline
\end{tabular}


Journal of Applied Management and Accounting Science ( J A M A S )

(Pande Made Widiarjaya WD, I Gede Juliana Eka Putra, I Nyoman Yudi Anggara Wijaya 1 - 11) Vol 2, No 1, Desember 2020

\section{Tabel 2}

Tabel Pengujian Black Box pada Tambah Stok Produk

\begin{tabular}{|c|c|c|c|}
\hline No & $\begin{array}{c}\text { Skenario } \\
\text { Pengujian }\end{array}$ & $\begin{array}{l}\text { Hasil yang } \\
\text { Diharapkan }\end{array}$ & Kesimpulan \\
\hline 1 & $\begin{array}{l}\text { Mengosongkan } \\
\text { inputan lalu klik } \\
\text { tombol "Simpan", }\end{array}$ & $\begin{array}{l}\text { Sitem tidak akan } \\
\text { menyimpan data dan } \\
\text { menampilkan pesan } \\
\text { "Peringatan : please } \\
\text { fill out this field" }\end{array}$ & Valid \\
\hline 2 & $\begin{array}{l}\text { Mengisi inputan } \\
\text { jumlah stok, lalu } \\
\text { langsung klik } \\
\text { "Simpan" }\end{array}$ & $\begin{array}{l}\text { Sistem tidak akan } \\
\text { menyimpan data dan } \\
\text { menampilkan pesan } \\
\text { "Peringatan: please } \\
\text { fill out this field } \\
\text { Jumlah Susu" }\end{array}$ & Valid \\
\hline 3 & $\begin{array}{l}\text { Mengisi inputan } \\
\text { jumlah stok dan } \\
\text { jumlah susu, lalu } \\
\text { klik "Simpan" }\end{array}$ & $\begin{array}{c}\text { Sistem akan } \\
\text { menyimpan data } \\
\text { inputan ke database } \\
\text { dan menampilkan } \\
\text { pesan "Data Stok } \\
\text { Berhasil Disimpan" }\end{array}$ & Valid \\
\hline
\end{tabular}

Tabel 3

Pengujian Black Box pada Menu Tambah Bahan Baku

\begin{tabular}{|c|c|c|c|}
\hline No & $\begin{array}{c}\text { Skenario } \\
\text { Pengujian }\end{array}$ & $\begin{array}{l}\text { Hasil yang } \\
\text { Diharapkan }\end{array}$ & Kesimpulan \\
\hline 1 & $\begin{array}{c}\text { Mengklik } \\
\text { tombol tambah } \\
(+) \text { pada tambah } \\
\text { bahan baku }\end{array}$ & $\begin{array}{c}\text { Sistem akan } \\
\text { menampilkan form } \\
\text { tambah bahan baku }\end{array}$ & Valid \\
\hline 2 & $\begin{array}{l}\text { Mengosongkan } \\
\text { semua inputan, } \\
\text { lalu langsung } \\
\text { klik tombol } \\
\text { "Simpan } \\
\text { Bahan" }\end{array}$ & $\begin{array}{l}\text { Sistem tidak akan } \\
\text { menyimpan data } \\
\text { dan menampilkan } \\
\text { pesan "Peringatan: } \\
\text { seluruh inputan } \\
\text { harus diisi" }\end{array}$ & Valid \\
\hline 3 & $\begin{array}{l}\text { Mengisi inputan } \\
\text { Nama Bahan, } \\
\text { lalu langsung } \\
\text { klik tombol } \\
\text { "Simpan" }\end{array}$ & $\begin{array}{l}\text { Sistem tidak akan } \\
\text { menyimpan data } \\
\text { dan menampilkan } \\
\text { pesan "Peringatan: } \\
\text { Jumlah bahan dan } \\
\text { Satuan harus diisi", }\end{array}$ & Valid \\
\hline 4 & $\begin{array}{c}\text { Mengisi inputan } \\
\text { Nama Bahan } \\
\text { dan Jumlah } \\
\text { Bahan, lalu } \\
\text { langsung klik } \\
\text { tombol } \\
\text { "Simpan" }\end{array}$ & $\begin{array}{l}\text { Sistem tidak akan } \\
\text { menyimpan data } \\
\text { dan menampilkan } \\
\text { pesan "Peringatan: } \\
\text { Satuan harus diisi" }\end{array}$ & Valid \\
\hline 5 & $\begin{array}{l}\text { Mengisi semua } \\
\text { inputan dengan } \\
\text { benar, lalu klik } \\
\text { tombol } \\
\text { "Simpan" }\end{array}$ & $\begin{array}{c}\text { Sistem akan } \\
\text { menyimpan data ke } \\
\text { database dan } \\
\text { menampilkan pesan } \\
\text { "Data Bahan } \\
\text { berhasil disimpan" }\end{array}$ & Valid \\
\hline
\end{tabular}


Journal of Applied Management and Accounting Science ( J A M A S )

(Pande Made Widiarjaya WD, I Gede Juliana Eka Putra, I Nyoman Yudi Anggara Wijaya 1 - 11) Vol 2, No 1, Desember 2020

\section{Tabel 4}

\section{Pengujian Black Box pada Menu Tambah Kategori}

\begin{tabular}{|c|c|c|c|}
\hline No & Skenario Pengujian & $\begin{array}{l}\text { Hasil yang } \\
\text { Diharapkan }\end{array}$ & Kesimpulan \\
\hline 1 & $\begin{array}{c}\text { Mengklik tombol } \\
\text { tambah }(+) \text { pada } \\
\text { tombol tambah } \\
\text { kategori }\end{array}$ & $\begin{array}{c}\text { Menampilkan form } \\
\text { untuk menginput } \\
\text { tambah kategori }\end{array}$ & Valid \\
\hline 2 & $\begin{array}{l}\text { Mengosongkan } \\
\text { inputan, lalu } \\
\text { langsung klik } \\
\text { tombol "Simpan } \\
\text { Kategori" }\end{array}$ & $\begin{array}{l}\text { Sistem tidak akan } \\
\text { menyimpan data } \\
\text { dan menampilkan } \\
\text { pesan "Peringatan: } \\
\text { Kategori harus } \\
\text { diisi" }\end{array}$ & Valid \\
\hline 3 & $\begin{array}{c}\text { Mengisi inputan } \\
\text { nama kategori, lalu } \\
\text { klik tombol } \\
\text { "Simpan Kategori" }\end{array}$ & $\begin{array}{c}\text { Sistem akan } \\
\text { menyimpan data di } \\
\text { database dan } \\
\text { menampilkan } \\
\text { daftar kategori }\end{array}$ & Valid \\
\hline
\end{tabular}

Tabel 5

Pengujian Balck Box pada Menu Tambah Produk

\begin{tabular}{|c|c|c|c|}
\hline No & $\begin{array}{c}\text { Skenario } \\
\text { Pengujian }\end{array}$ & Hasil yang Diharapkan & Kesimpulan \\
\hline 1 & $\begin{array}{l}\text { Mengklik tombol } \\
\text { tambah Produk }\end{array}$ & $\begin{array}{c}\text { Sistem akan } \\
\text { menampilkan form } \\
\text { untuk menginput data } \\
\text { produk }\end{array}$ & Valid \\
\hline 2 & $\begin{array}{l}\text { Mengosongkan } \\
\text { semua inputan, } \\
\text { lalu langsung } \\
\text { klik tombol } \\
\text { "Simnan Produk" }\end{array}$ & $\begin{array}{c}\text { Sistem tidak akan } \\
\text { menyimpan data dan } \\
\text { menampilkan pesan } \\
\text { "Lengkapi semua data" }\end{array}$ & Valid \\
\hline 3 & $\begin{array}{l}\text { Mengisi inputan } \\
\text { Kode Produk, } \\
\text { lalu klik tombol } \\
\text { "Simpan Produk" }\end{array}$ & $\begin{array}{c}\text { Sistem tidak akan } \\
\text { menyimpan data dan } \\
\text { menampilkan pesan } \\
\text { "Peringatan: Nama } \\
\text { Produk, Kategori } \\
\text { Produk, Harga Produk } \\
\text { harus diisi" }\end{array}$ & Valid \\
\hline 4 & $\begin{array}{l}\text { Mengisi inputan } \\
\text { Kode Produk dan } \\
\text { Nama Produk, } \\
\text { lalu klik tombol } \\
\text { "Simpan Produk" }\end{array}$ & $\begin{array}{l}\text { Sistem tidak akan } \\
\text { menyimpan data dan } \\
\text { menampilkan pesan } \\
\text { "Peringatan: Kategori } \\
\text { Produk dan Harga } \\
\text { Produk haru diisi" }\end{array}$ & Valid \\
\hline 5 & $\begin{array}{c}\text { Mengisi inputan } \\
\text { Kode Produk, } \\
\text { Nama Produk } \\
\text { dan Kategori } \\
\text { Produk, lalu klik } \\
\text { tombol "Simpan } \\
\text { Produk" }\end{array}$ & $\begin{array}{l}\text { Sistem tidak akan } \\
\text { menyimpan data dan } \\
\text { menampilkan pesan } \\
\text { "Peringatan: Harga } \\
\text { Produk haru diisi" }\end{array}$ & Valid \\
\hline 6 & $\begin{array}{c}\text { Mengisi semua } \\
\text { inputan dengan } \\
\text { benar, lalu klik } \\
\text { tombol "Simpan } \\
\text { Produk" }\end{array}$ & $\begin{array}{c}\text { Sistem akan } \\
\text { menyimpan data ke } \\
\text { database dan } \\
\text { menampilkan pesan } \\
\text { "Data Produk berhasil } \\
\text { ditambahkan" }\end{array}$ & Valid \\
\hline
\end{tabular}


Journal of Applied Management and Accounting Science ( J A M A S )

(Pande Made Widiarjaya WD, I Gede Juliana Eka Putra, I Nyoman Yudi Anggara Wijaya 1 - 11)

Vol 2, No 1, Desember 2020

\section{Pengujian Black Box pada Menu Transaksi Baru}

Tabel 6

\begin{tabular}{|c|c|c|c|}
\hline No & Skenario Pengujian & $\begin{array}{l}\text { Hasil yang } \\
\text { Diharapkan }\end{array}$ & Kesimpulan \\
\hline 1 & $\begin{array}{c}\text { Mengosongkan } \\
\text { semua inputan, lalu } \\
\text { langsung klik tombol } \\
\text { "Tambahkan" }\end{array}$ & $\begin{array}{l}\text { Sistem tidak akan } \\
\text { menyimpan data dan } \\
\text { menampilkan pesan } \\
\text { "Lengkapi Semua } \\
\text { inputan" }\end{array}$ & Valid \\
\hline 2 & $\begin{array}{c}\text { Menginputkan } \\
\text { produk, lalu klik } \\
\text { tombol "Tambahkan" }\end{array}$ & $\begin{array}{l}\text { Sistem tidak akan } \\
\text { menyimpan data dan } \\
\text { menampilkan pesan } \\
\text { "Lengkapi Semua } \\
\text { inputan" }\end{array}$ & Valid \\
\hline 3 & $\begin{array}{l}\text { Menginputkan } \\
\text { produk dan jumlah, } \\
\text { lalu klik tombol } \\
\text { "Tambahkan" }\end{array}$ & $\begin{array}{c}\text { Sistem akan } \\
\text { menampilkan proses } \\
\text { transaksi }\end{array}$ & Valid \\
\hline 4 & $\begin{array}{c}\text { Klik tombol "Proses } \\
\text { Transaksi" }\end{array}$ & $\begin{array}{c}\text { Sistem akan } \\
\text { menyimpan data } \\
\text { transaksi di database } \\
\text { dan menampilkan } \\
\text { pesan "Transaksi } \\
\text { Berhasil" }\end{array}$ & Valid \\
\hline
\end{tabular}

\section{SIMPULAN DAN SARAN Simpulan}

Berdasarkan hasil pembahasan pengembangan Sistem Informasi Enterprise pada Bali Etawa Farm, adapun kesimpulan yang didapat penulis adalah sebagai berikut :

a. Telah berhasil dibuat pada penelitian ini berupa Sistem Informasi Enterprise pada Bali Etawa Farm.

b. Sistem Informasi Enterprise pada Bali Etawa Farm terdapat beberapa point didalam sistem yaitu Admin, Produksi, Gudang dan penjualan dimana setiap bagian tersebut dapat terintegrasi mulai dari produksi hingga sampai ke penjualan dan owner dapat memonitoring setiap proses yang ada.

c. Hasil pengujian yang dilakukan menggunakan metode black box testing berjalan dengan baik dan sesuai dengan harapan sehingga sistem sudah siap diimplementasikan sebagai tahap percobaan.

\section{Saran}

Dengan adanya Sistem Informasi Enterprise pada Bali Etawa Farm untuk kedepannya pengembangan sistem diharapkan dapat dikembangkan menjadi server daerah sehingga dapat mengangkat bisnis menjadi lebih besar.

\section{DAFTAR PUSTAKA}

L. M. R. F. Sintya Sukarta, 2015. "Rancang Bangun Enterprise Resource Planning (Modul Keuangan, Logistik, \& Sumber Daya Manusia) Pada Sentra Industri Kaos di Bandung Jawa Barat," Majalah Ilmiah Unikom, vol. 13, pp. 249-263.

M. Efrina, 2016. "Sistem Informasi Enterprise Resource Planing (ERP) pada UKM di Indonesia," Administrasi Bisnis, p. 6. 
Journal of Applied Management and Accounting Science ( $J$ A M A S )

(Pande Made Widiarjaya WD, I Gede Juliana Eka Putra, I Nyoman Yudi Anggara Wijaya 1 - 11) Vol 2, No 1, Desember 2020

C. Tristianto, 2018. "Penggunaan Metode Waterfall Untuk Pengembangan Sistem Monitoring dan Evaluasi Pembangunan Pedesaan," Jurnal Teknologi Informasi ESIT, vol. XII, pp. 8-22.

S. McCool, 2012. Laravel Stater : The definitive introduction to the Laravel PHP web development framework, Birmingham: Packt Publishing Ltd.

Aminudin, 2015. Cara Efektif Belajar Framework Laravel, Yogyakarta: Lokomedia.

M. Suhartanto, 2012. "Pembuatan Website Sekolah Menengah Pertama Negeri 3 Delanggu Dengan Menggunakan Php dan MySQL," Journal Speed, vol. IV, pp. 1-8.

Y. R. O. P. E. K. J. Andreas Handojo, 2003. "Pembuatan Aplikasi Sistem Pendaftaran Online Pada Jurusan Teknik Informatika Universitas Kristen Petra Dengan Menggunakan PHP," Jurnal Informatika, vol. IV, pp. 9-14.

M. F. Ramadhani, 2014. "Pembangunan Aplikasi Informasi, Pengaduan, Kritik, dan Saran Seputar Kota Cimahi pada Platform Android," Jurnal Ilmiah Komputer dan Informatika, pp. 1-9.

C. Hardjono, 2017. "Perancangan dan Implementasi ERP (Enterprise Resource Planning) Modul Sales and Warehouse
Management pada CV. Brada," e-Proceeding of Engineering, vol. Vol.4, pp. 4983-4993.

C. T. A. I. D. 2017. Vincensia Lusi Kurniawan, "Perancangan Sistem Informasi Dengan Metode Enterprise Resource Planning (ERP) Untuk Manajemen dan Inventori Pada Apotek Kharisma Farma Denpasar," Jurnal Teknologi Informasi dan Komputer, vol. Volume 3, pp. 295-303. 